\title{
Project Failure: The Way forward and Panacea for Development
}

\author{
T. Zuofa ${ }^{1} \&$ E. G. Ochieng ${ }^{2}$ \\ ${ }^{1}$ Westminster Business School, University of Westminster, London, United Kingdom \\ ${ }^{2}$ School of the Built Environment, Liverpool John Moores University, Liverpool, United Kingdom \\ Correspondence: T. Zuofa, Westminster Business School, University of Westminster, London, United Kingdom. \\ E-mail: t.zuofa@westminster.ac.uk
}

Received: August 27, 2014

Accepted: September 23, 2014

Online Published: October 22, 2014

doi:10.5539/ijbm.v9n11p59

URL: http://dx.doi.org/10.5539/ijbm.v9n11p59

\begin{abstract}
There is an unambiguous relationship between development and the successful execution of projects as well as societal wellbeing. This paper examined the concept of project failure. The rationale was to identify the main factors responsible for project failure and suggest strategies aimed at curbing project failure and facilitating development in the future. Data was obtained from a focus group comprising of eight project management practitioners in Nigeria. The results were recorded, transcribed and entered into the qualitative research software NVivo. Validity and reliability were achieved by first assessing the plausibility in terms of already existing knowledge on some of the issues raised by the focus group participants. The emerging key issues suggested that project failure may be contingent on several factors but established based on consensus that corruption and lack of professionalism were among the main causes of project failure in Nigeria. The main results were further synthesised into action points which included: the need for an introduction of governance mechanism to incorporate processes standard guidelines that supports projects to achieve their objectives, enshrining punitive actions against erring project stakeholders who engage in corrupt and unethical practices.
\end{abstract}

Keywords: corruption, developing countries, development, Nigeria, project failure

\section{Introduction}

Nigeria can be considered a leading developing country. With a population of approximately 154.7 million people the nation prides itself as the most populous country in Africa (World Bank, 2013). This figure comprises of over 250 diverse ethnic groups presently dispersed among thirty-six states and the nation's federal capital territory. The fragmentations from the numerous ethnic groups have been relatively balanced by the country's federal structure which places an emphasis on equal representation. Details from the International Fund for Agricultural Development Country Evaluation Report (2009) highlighted that Nigeria's Gross Domestic Product (GDP) increased five-fold since 1990 and stood at US\$140 billion in 2007. This gave a GDP per capita of over US $\$ 1,000$ and an anticipated, consistent current-account surplus of ten per cent of GDP annually. However, there is ample evidence to show that the vast majority of the Nigerian populace are still among the poorest in the world. According to the Vision 2020 National Technical Working Group Report (2009), Nigeria is ranked 158 out of 177 nations in its Human Development Index and 80 out of 108 in the Poverty Index. Income disparity and widespread poverty still persist despite flourishing foreign revenues generated from its vast crude oil reserves.

Literature highlight claims of under development and a dearth of infrastructure in various parts of Nigeria (Babalola, 2014; Felix \& Wilson, 2011; Uma, Eboh, Obidike \& Ogwuru, 2013). In view of this, Zuofa and Ochieng (2012) proposed that the execution of roads, dams, rural water supply and other infrastructure projects which support development should be imperative in Nigeria and other developing countries because such projects instigate development and contribute towards the alleviation of the effects of most social, political and economic problems. From hindsight, perhaps several projects which would have impacted positively on the overall wellbeing of the Nigerian state may have failed entirely or else failed to achieve their major purposes. The surprising turn of events associated with the outcome of such projects from the past years provide a suitable context for the aim of this paper. This paper therefore focused on examining project failure in Nigeria based on the experiential knowledge of selected project practitioners. The findings from this research have reasonable implications as it provides insights into the several factors responsible for project failure in Nigeria and proposed 
solutions towards curbing failure in future projects. The rest of the paper is structured as follows: the subsequent section provides an overview of relevant literature, after which the research method utilised is introduced, then results are discussed and conclusions drawn.

\subsection{A Perspective Based Understanding of Project Success and Failure}

Evidence abounds that recognising what constitutes success or failure in project management literature has remained vague (Ika, 2009; Thomas \& Fernandez, 2008; Baccarini, 1999; Jugdev \& Muller, 2005). So far, what can be concluded from most studies on project success and failure is that notwithstanding their frequent usage, there are still disagreements on how best to define success and failure. It is for such reasons that Wateridge (1998) suggested that success or failure should not be construed as black and white elements. Therefore, a perspective based understanding of project success and failure has been undertaken in the review of literature.

Generally, the varying sizes and complexities inherent in projects create an additional uniqueness for any individual project. This uniqueness also makes the mechanism wherein stakeholders interpret success to be at variance. As such, Westerveld (2003) concluded that it is unlikely to have a common set of criteria for determining project success. Traditional project management attempted to define and measure success by just using the triple criteria of time, budget and quality (Atkinson, 1999; Cooke-Davies, 2002; Jugdev \& Muller, 2005). Over the years, research has construed success from diverse dimensions thereby incorporating additional criteria. For instance, Lim and Mohamed (1999) defined project success by the use of micro and macro criteria. The micro criteria include time, cost, quality, performance and safety while the macro criteria comprised of the micro criteria as well as the project deliverables during the operational phase. Other dimensions to project success include customer satisfaction (Belassi \& Tukel, 1996; Raz \& Michael, 2001; Zwikael \& Globerson, 2004), business success generally in terms of profitability as well as those that consider accomplishing organisational objectives (Thomas \& Fernandez, 2008; White \& Fortune, 2002) as well as customer satisfaction (Dvir, 2005; Pinto \& Slevin, 1988; Thomas \& Fernandez, 2008).

From most of the dimensions on project success examined, it can be concluded that the perceptions of success differ among individuals, industry and project typologies. However, most of these perceptions can be categorised into two broad types. The first being those that perceive project success from the subjective perspective; for instance based on individual or group satisfaction while the second comprises of the objective perspective which adjudge success based on tangible factors like cost and quality. While the debate on what may exactly be considered as project success may linger, this paper positions its perspective of success to be based on achieving projects within the limits of cost, time and schedule as well as the stakeholders satisfaction of the project. With this definition, project success becomes less debatable and can be viewed from both short and long term perspectives.

Similarly to project success, most attempts to gain greater comprehension of the concept project failure have been difficult. From an elementary perspective, failure can be considered as the lack of success or an inability to achieve success in an endeavour. With the highly contentious nature of success, determining a lack of success becomes even more complicated! It is perhaps for this and other reasons that, Pinto and Mantel (1990) submitted that the concept of project failure has also remained nebulous. The difficulties associated in defining project failure can be traceable to the lack of consensus of the concept, limited empirical studies on the systematic causes of failure, the project taxonomy and its lifecycle. Despite these difficulties, Pinto and Mantel (1990) still utilised empirical evidence to conclude that project failure is influenced by how failure is defined among the project stakeholders, the type of project and the stage under assessment in the lifecycle of the project.

What then constitutes project failure? Most frequently projects are considered failures when they fail to meet their targeted cost, time, or scope. However, Ika (2012) demonstrated that projects may be completed within their targeted time, cost and scope criteria but still be classified as failures. Therefore, it becomes necessary to consider failure beyond these criteria and include targets such as the aspiration of stakeholders, the benefits accruing to society or project organisation among criteria for determining project failure. Several researchers including Nelson (2005) support this notion and have equally criticised defining project failure by just using cost, time, scope and other traditional indicators; arguing that value added assessment criteria like project usefulness, value to organisations and learning potential must be considered when evaluating project failure.

So far, attempts have been made to shed light on project success and failure by examining existing literature on the expectations and evaluations of success and failure. In doing so, a consensus has been reached that there are no common definitions of success or failure. Hence an in-depth understanding of these terms will emerge from the activities undertaken during the lifecycle of specific projects under evaluation and based on stakeholder definitions, measurements and interpretations. Therefore it will be undisputable to suggest that project success or 
failure is simply matters of perception. Despite this controversy, this paper follows the broad definition of project failure according tolka (2012). To this end, project failure exceeds the inability to meet stipulated schedules, cost and quality but can also include an inability to achieve the functional requirements of projects as perceived by stakeholders.

\subsection{Development and the Nigerian Society}

Until the return of democratic rule, Nigeria was characterised by a series of military dictatorships and economic mismanagement. Following these years of military rule and poor economic management, Okonjo-Iweala and Osafo-Kwaako (2007) observed that Nigeria has experienced prolonged periods of economic stagnation, rising poverty levels and decline of its public institutions. Furthermore, they stated that the lack of public investments in previous decades have resulted in severe infrastructural bottlenecks that hindered private sector activities. Others (Zuofa \& Ochieng, 2012; Okorafor \& Adu, 2010) observed that the country is still saddled with several challenges like governance, limited capacity for project management policy formulation and implementation, infrastructural deficit, high unemployment and poverty. However, the country still has enormous potential and opportunities which if efficiently and effectively harnessed will accelerate the rate of economic growth and job creation. For this reasons, the African Development Bank (2013) posited that Nigeria's outlook for economic growth remains positive. Additionally, it is the Federal Government of Nigeria's aspiration that by the year 2020, Nigeria will have a large, strong, diversified, sustainable and competitive economy that effectively harnesses the talents and energies of its people and responsibly exploits its natural endowments to guarantee a high standard of living and quality of life for its citizenry.

Projects in any form such as transport, power generation and distribution, health, education, defence/ military, water services, waste disposal are central to the development of any nation (Srinivasu \& Rao, 2013; Sahoo \& Dash 2009). Appreciating this, the present Federal Government in Nigeria adopted the Vision 20:20 policy. The Vision 20:20 policy can be described as the overarching policy framework for Nigeria to become one of the top twenty economies in the world by the year 2020. Towards implementing the vision 20:20, a medium-term strategy, the Transformation Agenda which is billed to run from 2011-2015 was devised and articulated around nine thematic objectives(Nigerian Vision 20:2020 Economic transformation Blueprint). Among the thematic objectives are infrastructure development, the distribution of key programmes and projects by sector; financing and implementing strategies for the key policies, programmes, and projects; as well as their monitoring and evaluation. Evidence from the government's transformation agenda highlights the high importance projects and infrastructure development have been accorded. And Foster and Pushak (2011) observed thatNigeria has made important strides towards improving its infrastructure when compared to other African nations.

\subsection{An Appraisal of Selected Projects in Nigeria}

Earlier sections provided an overview of project success and failure. A brief analysis of projects in Nigeria has been undertaken to grasp a better understanding of their characteristics in terms of their outcomes (failures or success). It must be cautioned that the projects examined here do not reflect the totality of all projects in Nigeria rather they are a representation of information from several public and private sector driven projects available in the public domain. From the transport and infrastructure sector, The Lagos BRT-Lite Summary Evaluation Report (2009), revealed that the first African Bus Rapid Transit (BRT) designated Lagos BRT-Lite Scheme became operational from March 2008 in Lagos, the financial capital of Nigeria. The project which cost about $\$ 1.7$ million per $\mathrm{km}$, covered approximately $22 \mathrm{~km}$ was considered reasonable when compared to the costs of similar projects around the world. Direct and indirect stakeholders of this project like the Lagos State Government, Mobereola (2009) as well as commuters have suggested that this transport system now meets the needs of local users, boosts economic efficiency and was also undertaken with a clearly defined budget and in adherence to safety standards. Mobereola (2009), added that the success of the Lagos BRT-Lite was not solely from its infrastructure but from a holistic approach that included reorganizing the bus industry, financing new buses, creating a new institutional structure and regulatory framework to support the system and training the personnel needed to drive, maintain, enforce and manage it as well as creating public awareness about the new transportation system. Similarly, the Infrastructure Concession Regulatory Commission (ICRC) identified the Murtala Muhammed Airport Two (MMA2) as a legacy project in Nigeria. This $\$ 150$ million project which is now in operation was built through a public-private partnership between the Nigerian federal government and Bi-Courtney Limited on a build, operate and transfer basis. It comprises of the airport terminal, a multi-storey car park, an apron, a four-star hotel and a conference centre. Reports from the Nigerian energy sector equally indicate some outstanding feats like Shell's Bonga offshore field development project which became Nigeria's first deepwater oil discovery. The field was discovered and developed in 2005 using several novel technologies at a cost of nearly $\$ 3.6$ billion (Offshore Technology, n.d.). While later phases of the Addax Okwori and Antan 
projects located offshore Nigeria were completed on schedule and budget with no security or HSE incidents (Subsea, 2011). Also, since 2007, various phases of The Tinapa Free Zone and Resort, Africa's Premier Business Resort and the only retail and tourism based Free Zone in Nigeria have been commissioned for use. Globacom made history by successfully laying Glo-1; a $\$ 800$ million high-capacity fibre-optic submarine cable, the first of its kind from Nigeria to the United Kingdom to enhance mobile communication from Nigeria (Glo, n.d.).

However, there are also less impressive records concerning the outcomes of other Nigerian projects. In the extant body of literature on project failure in Nigeria, Ubani, Nwachukwu and Nwokonkwo (2010) suggested that after the Nigerian independence in 1960, many developmental projects have suffered failure and abandonment. Okereke (2012) examined projects from various sectors in Nigeria and highlighted several shortcomings and achievements. According to Okereke (2012), there is ample evidence to suggest that project failure was not confined to any state but could rather be termed as a national malaise. In conclusion, it was observed that it may be difficult to find projects in the public sector that have been completed on time and within budget. In another development, concerned with the abysmal performance of the Niger Delta Development Commission (NDDC), the present government set up a committee to appraise the activities of the commission. Part of the finds of the Presidential Monitoring Committee on NDDC available on the Daily Times revealed that of 609 projects monitored, 285 projects representing about 46.8 per cent were abandoned at various levels of completion; 222 projects representing about 36.5 per cent were completed while another 102 projects (16.7 per cent) were on-going (Daily Times, 2013). Additionally, Enagi and Ochoche (2013) held that despite the huge Nigerian government investments, notable IT projects have failed. Their premise was based on an evaluation of various projects in Nigeria like the Abuja Investment and Property Development Company (AIPDC) which lost about 3.8billion naira over four years due to failed IT projects as well as the Energo Nigeria Limited transmission substation that achieved less than 5 per cent implementation from 2008. As a final point, Ewa (2013) disclosed that in the midst of the anticipated benefits of capital project implementation, most projects executed in Nigerian tertiary institutions fail to accomplish their objectives.

All of the foregoing generates valid concerns about the state of projects and other infrastructure executed in Nigeria in terms of their failure or success. This is because there is considerable evidence within the body of literature that establishes a relationship between infrastructure capital such as projects and economic growth (PWC, 2014). More importantly, because the current government has identified critical infrastructure development like power, roads transportation, and railways; and agricultural transformation, as key to its operational success and the accomplishment of its Vision 2020 policy. It is against this background that a qualitative evaluation of project failure from selected projects in Nigeria was performed to identify militating issues and reflect on how such issues can be handled in future to reduce the rate of project failures. To achieve this, the paper adopted a different approach by shifting from just projects in specific sectors to broadly empirically concentrating on projects from diverse sectors based on the accounts of selected project management practitioners. With this approach, cross-learning for future projects can be further achieved.

\section{Method}

The objective of this paper was to evaluate project failure in Nigeria. To address this, a qualitative research approach was most favourable. Creswell (2009) described the qualitative research as an inquiry process of understanding based on distinct methodological traditions of inquiry that explore a social or human experience. It facilitates the sharing of the understanding and perceptions of human beings and phenomena, thereby making it an in-depth and detailed means of gathering information. The qualitative research approach highlights a thoughtful and detailed description of social practice while attempting to understand individual's perspectives of their world. In line with the above, interpretivism was identified as the epistemological framework for the paper because of the subjective and perceptive nature of the subject under consideration-project failure. The subjective and perceptive nature of the subject required the interpretation and description of what constitutes project failure before carrying out any further evaluation. In this regard, there was a great reliance on the participant's ideas of project failure.

Purposive sampling was utilised for the selection of the sample. The sample mainly comprised of key project management practitioners involved in diverse projects drawn from industry, academia and government agencies. An initial set of twenty participants was contacted; the aim of contacting a large number of prospective participants was to curtail difficulties that may arise from any participant's declination. Finally, just eight of those contacted accepted to participate while the others declined mainly based on ethical reasons and other unexplained personal reasons. Table 1 highlights the profile of the participants and provides further details of their activities. To maintain the confidentiality of all participants, alphabetical coding was utilised. 
Table 1. Profile of focus group participants

\begin{tabular}{|c|c|c|c|}
\hline $\begin{array}{l}\text { Participant } \\
\text { code }\end{array}$ & Designation & $\begin{array}{l}\text { Period of involvement with projects } \\
\text { in Nigeria (years) }\end{array}$ & Project Category \\
\hline A & Project manager & 14 & Housing, roads, tertiary institution complexes \\
\hline B & $\begin{array}{l}\text { Consultant / Government } \\
\text { adviser on projects }\end{array}$ & Over 25 & $\begin{array}{l}\text { Civil construction, shoreline protection and } \\
\text { reclamation }\end{array}$ \\
\hline $\mathrm{C}$ & Project director & 13 & Housing, roads, drainages \\
\hline $\mathrm{D}$ & Lecturer/ consultant & 19 & $\begin{array}{l}\text { Markets, roads, offices (including various } \\
\text { government secretariats) }\end{array}$ \\
\hline $\mathrm{E}$ & Managing partner & 15 & Rural electrification, roads, schools \\
\hline $\mathrm{F}$ & Technical associate & Over 11 & Roads, bridges and schools \\
\hline G & Project coordinator & 17 & Roads, water supply, irrigation \\
\hline $\mathrm{H}$ & Project manager & 18 & Rural electrification, roads, schools \\
\hline
\end{tabular}

As highlighted in Table 1, all the participants had significant project management experience and had participated in projects as project managers, project directors, consultants or government advisers. Among the criteria used for the participant selection was their length of involvement in private and government sponsored projects; all participants had more than ten years practical experience in project management and had handled various categories of projects across Nigeria.

Data was collected by an organised focus group session. The choice of focus groups for this paper was because it proved to be a quick, flexible and economical method of gathering in depth information. According to Ghauri and Gronhaug (2010), focus groups allow researchers interact directly with participants and build upon the discussion as it progresses. To ensure that the aim of the focus group was achieved, an experienced moderator was utilised. The moderator instigated discussions and ensured that the entire session was hitch free with limited digressions. Prior to the commencement of the session, a list of questions reflecting the purpose of the discussion was handed over to the moderator. A "funnel" technique was adopted for the structure of the focus group, which meant more general questions were asked at the start to break the ice, followed by more specific questions which required more technical reflection in relation to the participants' appraisal of project failure in Nigeria (Bryman \& Bell, 2011). As shown in the appended focus group discussion guide (Appendix. A), engagement/ contextual questions, exploration/probing questions and exiting questions were used. All the questions were framed based on the insights from the initial literature review which investigated project failure in Nigeria as well as the researchers' practical knowledge of the subject.

The moderator also informed the participants that no identifying information will be utilised during the final production of the paper and appealed to all participants to try their best to engage during the session but also expressed the likelihood of permitting their silence where contentious issues get raised. The discussion lasted for approximately one hour and twenty minutes. Afterwards, the data was analysed by adopting the following steps: organising the data; categorising the data, building of themes and patterns, understanding emerging concepts and writing up. The validation took place after the verification process; this involved presenting the findings to a different set of participants who were not involved with the study. This was achieved using another focus group discussion.

The philosophical consideration of this research can be viewed from two broad perspectives. The first was linked to the essential requirement of investigating project failure in Nigeria. The second was linked to the need to select a research strategy that enabled the collection of rich qualitative data. The findings were presented based on emergent themes from the analysis; where appropriate, direct quotations were used to further express views of the participants.

\section{Findings}

Several remarkable and informative points were raised during the focus group discussion. The participants collectively acknowledged the relevance of the subject to the Nigerian society, project management practice as well as their current and future activities. According to most participants the forum provided an additional means of reflecting on current issues concerning the state of past and current projects and what can be done to facilitate 'more successful' projects in future.

\section{Theme 1: Defining project failure}

There were a plethora of responses but most participants' accounts on the definition on project failure were 
rather vague; participants (D, H, E, and G) found explaining the characteristics of failure less burdensome as compared to actually defining what they perceived as project failure. For this reason, the moderator attempted contrasting the definition of project failure from project success. To achieve this, the moderator sought the participant's opinions on project success. What emerged was a plethora of responses; for instance, Participant (F) referred to the completion of a major bridge project linking riverine communities in the Niger Delta region to describe project success. According to the participant, 'after several delays, the successful and timely completion of this transformation project further solidified our reputation for delivering major projects on-time and within budget'.

Participant (A) commented that projects are successful if they meet project performance criteria such as an adherence to technical specifications, delivered reasonable benefits to the project organisation, clients and other stakeholders. In the midst of the varying responses, what became most common was that projects were deemed successful when they met their anticipated quality, time and stakeholder satisfaction.

Then, a follow-up question to find out the necessary constituents for projects to be considered as failures also elicited several responses. Participant (D) opined that projects can be considered as failures, 'when projects do not level up to the satisfaction of the stakeholders or when the users have several complains'.

For another, it was if the project quality is poor. For participant (C), project failure occurs, 'when projects fail to meet the criteria of time, cost, and effectiveness. So you see, it does not mean if the project has been physically completed but the question is when was the completion? Is the quality specified standard reached or is the potential of the project really maximised. Strictly speaking, for me once there is a no to any of these questions, we can say what occurs is project failure'.

Other perceptions of project failure articulated by the participants included, 'the objectives have not been achieved in the specified time frame and when the project objectives are not achieved with the stipulated budget and time'.

\section{Theme 2: Project Failure: Tales from Past Experience}

Even as a precise definition of what constitutes project failure was not achieved, participants relived their past experiences to identify several factors responsible for project failure in Nigeria. Participant (E) suggested that from past experience, 'project failure is usually a result of inadequate planning and project financing, bankruptcy of contractors or other problems associated with sub-contractors, project scope variations, political influences, incompetent personnel and delays in payments'.

The common factors identified by most participants as responsible for project failure in Nigeria included poor project planning, weak business case, poor technology, stakeholders' management, lack of senior management involvement, funds mismanagement by contractors, untimely delivery of construction materials/ inefficient supply chain machinery. Other factors identified included project management issues, scope creep, lack of clear cut project objectives, improper planning, lack of integrating and alignment projects into corporate strategies, environmental issues, limited project management vision and poor engineering design. When inadequate budgetary allocation was mentioned by a particular participant, there were mixed reactions as several other participants argued against its inclusion and suggested that most budgetary issues affecting projects should be associated with corruption.

Participants also cited their experiences of project failure from past projects. Participant (A) articulated that, 'during the execution of a state government educational institution project, contracts were awarded but project could not commence because of several hitches and bureaucracies. When we eventually kicked-off several months behind schedule, we realised that variance arose from actual contractual figures. Many other issues came up too and all this brought delays, then suspension of the project. Till date, my records have it that the project was never completed. My team was ready to deliver but our hands were just tied so things did not work'.

All attempts to get the participant to further explain the statement "our hands were just tied" were futile as the participant was unwilling to provide further information. Participant (B) blamed project failure in Nigeria on the lack of continuity in government policies and vision. The participant stated that, "when a new political party or government takes over, they come up with white elephant projects and utopian polices. Today it is this one, tomorrow it is that one. Most times, they end up discontinuing existing projects or just suffocating anyone they don't like'.

In a recollection of past experience of project failure, Participant (D) cited the design and construction of an auditorium for local government council. The participant stated that, 'we were mandated to complete the auditorium for the local government council just a few months before the elections. On our part there were so 
many uncertainties and factors we considered while monies were not always released timely. Happily they got re-elected and although we managed to complete, this was done six months later and by this time the elections were over. A few threats and penalties were imposed as such we experienced cost overruns. Looking back, I can say what greatly lacked was a poor management of the scope and timing for the project as well as reasonable cooperation from the local government officials'.

Participant $(\mathrm{H})$ recounted that low level of education and imposition of project team members by community leaders, the uncoordinated involvement of youth groups in community-based projects, poor monitoring and evaluation by government officials were among the events that led to the failure of a rural electrification project. When put together, it emerged that several factors were responsible for project failure in Nigeria. However, it was collectively agreed that project failures in most projects in Nigeria largely originated from corruption at various levels, lack of professionalism, inexperienced project managers and project personnel, bureaucratic procurement process and the lack of skills and proven approach to project and risk management.

\section{Discussion}

The various explanations of project failure recounted by the participants provide ample evidence to suggest that the concept of project failure remains largely indefinable. This corroborates earlier studies (Ika, 2009; Nelson, 2005; Baccarini, 1999; Jugdev \& Muller, 2005) on the lack of congruence of expert opinions on project failure. Previous sections in this paper provided an account of varying opinions of project failure. What may be inferred from past literature and the accounts of the focus group participants is that definitions of project failure will emerge from the activities undertaken during the lifecycle of projects under scrutiny and based on stakeholder interpretations. For which reason, project failure retains its imprecise definition and may simply be a construction of stakeholder perception (Pinto \& Mantel, 1990). However, the evidence from literature and the focus group participants aptly summarised project failure as an inability to meet the aspirations of project stakeholders at various phases of projects or in the project's entirety.

Corruption, lack of professionalism, inexperienced personnel and lack of requisite skills were among the key issues identified as being responsible for most project failures in Nigeria. These issues identified by the focus group can be closely linked to the summaries of current and past studies on the main causes of project failure in Nigeria. For instance, Olalusi and Otunola (2012) identified incorrect estimation; lack of available skilled personnel; inadequate planning; poor risk management; misunderstanding of the work requirement; corruption to be among reasons for failed construction projects in Nigeria. In the same way, in an assessment of performance indices of ICT projects in the Nigerian public sector, Akinyokun, Angaye and Ubaru (2009) disclosed that failures in IT projects were still common in Nigeria. Their study attributed the failures to poor planning, lack of top management support, inadequate skill and expertise of IT project managers. Similarly, Oyewobi, Ganiyu, Oke, Ola-Awo and Shittu (2011) established that the causes of unethical project performance and retarded development in the Nigerian construction industry can be attributed to corruption and corrupt practices. Igbokwe-Ibeto (2012) examined issues and challenges affecting local government projects and concluded that corruption, inappropriate timing of budget releases, untimely payment of performance certificates, community and labour problems, contractor's default and inaccurate assessment of theproject environment have been responsible for failures in most local government sponsored projects in Nigeria. Finally, Ubaniet al. (2010) study on variation factors of project plans and their contributions to project failure in Nigeria identified design errors, management problems and resource delivery constraints as the significant variation factors that significantly contribute to project failure in Nigeria.

On the perceived lack of professionalism, inexperienced project managers and team members; granted that certain participants disclosed that project teams in Nigeria may comprise of personnel with high educational qualifications and project management skills while others may not. Odedairo, Oke and Oyalowo (2011) suggested that project management as a professional career path still remains unrecognised and largely unpatronised in Nigeria. This can also lead to a debate that there may also be gaps between what providers of project management learning are offering and what is needed to deal with the main issues affecting the generic project environment in Nigeria. Nonetheless, the need for sagacity in the deployment of project management skills can never be overemphasised during any project. For this and other reasons, Cleland and Gareis (2006) maintained that it is critical for all project team members to have an understanding of the fundamental project requirements and requisite project management skills. These requirements include project planning, risk management, organising, motivating, directing and controlling as well as maintaining a positive attitude.

Inadequate budgetary allocation was another debatable factor identified as being contributory to project failure in Nigeria. While this factor may be considered as highly relevant or otherwise among various schools of thought, 
it is instructive to note that Section 4 (2) (b) of the Nigerian Public Procurement Act 2007 stipulates that all procurement shall be based only on procurement plans supported by prior budgetary appropriations; and no procurement proceedings shall be formalised until the procuring entity has ensured that funds are available to meet the obligations. In none complex interpretation, this section highlights that the Nigerian law requires that contracts should only be awarded if funds are available for them from their onset. This clearly indicates that inadequate budgetary allocation should be a non-issue for project failure especially for government driven projects in Nigeria. However, Ewa (2013) and Okereke (2012) still highlight varying levels of failure partly attributable to inadequate budgetary allocations in most government projects.

On corruption, this paper is mindful of the political undercurrents that may drive the subject of corruption in Nigeria as such; it limits the discourse to the impact of corruption to infrastructure and development. Obayelu (2007) citing various studies averred that corruption is deeply entrenched in the Nigerian polity and has remained long-term major political and economic challenge for the nation. It is worth noting that corruption in Nigeria ranges from petty corruption to political / bureaucratic corruption or systemic corruption. It is described in various local parlance as greasing, softening the ground, inducements, sub-payments, side payments, irregular payments, payment under the table, undocumented extra payments, facilitation payments, mobilisation fees, routine governmental action, revised estimates, padded contracts, over (under)-invoicing, cash commissions, kickbacks, payoffs, covert exchanges, shady deals, cover-ups (Obayelu, 2007). As a consequence, Ameh and Odusami (2010) perceive that the international community views corruption and other unethical issues as common occurrences at all stages of the Nigerian workforce. With all these, it appears that Nigeria has failed to attain its economic potentials and corruption may be ascribed as one of the major factors aiding the country's limited infrastructure development and high rate of project failure. Nonetheless, Oyewobi et al. (2011) explained that corruption in construction projects can be eliminated if all participants in projects cooperate in the development and implementation of effective anti-corruption actions, which address the perpetrators of the ethical problems. The suggestions proffered above for curbing corruption in construction sector projects in Nigeria can be extended to projects executed in other sectors within the Nigerian society. It is also important for prospective project stakeholders to maintain a strict adherence to the Nigerian Public Procurement Act (PPA). According to the Bureau of Public Procurement, the PPA was introduced by government as a mandatory strategy for upholding transparency, prohibiting nepotism, inflation of reducing contract inflation and other corrupt acts in the award of government contracts. It is pertinent to state that while attaining a corrupt free society may not be feasible from the results of this paper or in the nearest future, what may be readily suggested to curb the menace of corruption within the Nigerian society and the broad project context can be achieved by a positive change in the attitudes of Nigerians (both the leaders and the led), as well as a reinvigoration of the present anti-corruption agencies activities. Furthermore, all stakeholders involved in project activities need to make concerted efforts to eschew all corrupt tendencies.

Additionally, the need for effective governance structures in both private and government organisations cannot be over emphasised. Effective governance can be seen as another remedy for corruption reduction as it supports suitability and predictability of the nation's developmental efforts as well as transparency. From a project management perspective project governance equally provides a comprehensive, consistent method of controlling projects and ensuring success (Project Management Institute, 2008). Without effective project governance system, projects may frequently encounter conflicts and inconsistencies among the various means of achieving their objectives, the products will not be efficient and the impacts of projects may become negative (Muller, 2009).

It is interesting to note that the key issues identified from the focus group as being responsible for project failure in Nigeria also seemed widespread in Africa. To support this notion, a few examples from across Africa can be mentioned. Firstly, Kakonge (1995) cited cases across several African countries and concluded that most agricultural projects in Africa have failed to achieve what was expected of them because of poor planning, lack of experience, bureaucratic inefficiency, technical incompetence, poor performance of government and donor agencies, project complexities. Likewise, Heeks (2002) explained that where e-government projects are introduced in Africa, they mainly end in either partial or total failure as a result of the disparities between project design and African public sector realities. Others like Agunga (1990) even suggested that poor management, more than anything else, is the main reason for the high failure rate of development projects in the third world, most of which includes Nigeria and other African countries. Koi-Akrofi, Quarshie and Koi-Akrofi (2013) observed that non-adherence to quality and schedules, wrong estimates as well as limited existence of project management departments responsible for the execution of projects were among the worrying areas that contribute to IT project failures in Ghana. To some extent from the above, there are practical reasons to suggest that even as countries have 
variable cultural and economic conditions, there are still indications that some African countries have common characteristics in terms of causes of project failure.

\subsection{The Way forward and Panacea for Development in Nigeria}

The effective and efficient planning, organising, directing and controlling of resources that facilitate the realisation of projects should be classified as a non-contentious aspiration among project stakeholders however, what remains somewhat of a paradox may be how best to achieve this aspiration. In addition to the issues identified and discussed, the following points condensed from the focus group discussion should be considered as action points and the way forward for curbing project failure in Nigeria:

- The introduction of a governance mechanism which incorporates processes and guidelines that supports projects to achieve their organisational objectives and also caters for the interests of both internal and external stakeholders;

- Government and organisations at all levels should instigate the establishment of project management offices (PMOs) as key departments in their agencies and ensure their functionality;

- Introduction of enhanced project management communication strategies. This is because the timely management of communication among relevant channels is critical for effective project management and delivery;

- Governments and organisations should accept the fact that, there are trained project management professionals. As a result, only such professionals should be involved in the management of their projects based on competence; and

- Enshrining punitive actions against erring project contractors, project managers and others directly or indirectly responsible for project failures especially as a result of corrupt and unethical practices.

It will also be important to adopt relevant project management methodologies or formulate distinct ones based on individual project circumstance. The findings also highlight the need for additional support for project management education and training. Finally, for any meaningful achievements to be made in future and to reduce the level of project failures, project management practitioners individually and collectively must urgently make deliberate efforts to rid corruption from their project operations.

\section{Conclusions and Limitations}

As shown in this paper, Nigeria is presently grappling with several challenges including infrastructure deficits. Available evidence abounds from literature on the relationship between infrastructure capital such as projects and economic growth. Therefore the need for a detailed understanding on why projects fail becomes pertinent as this facilitates synergistic continuous learning among individual and organised project stakeholders and ultimately supports the growing of their economies.

This paper examined project failure from selected projects in Nigeria. The relevance of the topic is grasped in the context in which project failure has confronted Nigeria. It also identified projects and their implementation to be among the thematic objectives of Nigeria's on-going transformation agenda. The findings affirmed that like in other climes, there is still a lack of consensus on the concept of project failure and success among project management practitioners in Nigeria. Specifically, it recognised that practitioners perceived project failure based on a variety of factors that exceed the inability to execute and deliver projects within defined cost, time or scope. The broad implication of this is that an in-depth understanding of project failure can only emerge from the activities undertaken during the lifecycle of projects and based on stakeholder definitions and criteria. However, it is worth noting that based on the consensus views from the focus group discussion, corruption, lack of professionalism, inexperienced project managers and project personnel, bureaucratic procurement process were identified as the main causes of project failure in Nigeria. The findings also highlighted the need for the introduction of governance mechanisms which integrate processes and guidelines that support projects to achieve their organisational objectives. Additionally, it was proposed that punitive actions should be enforced against erring project personnel who engage in corrupt and unethical practices.

On a cautionary note, the paper had certain limitations which need to be addressed in future. One important limitation was the size of participants available for the focus group. Another limitation was the choice of methodological approach which was purely qualitative. Future research may consider utilising quantitative analysis to ascertain any relationship between the identified causes of project failure in Nigeria. Even with these limitations, the findings of the paper still present important implications and thoughts for future projects undertaken in Nigeria and other countries with similar challenges. 


\section{References}

African Development Bank. (2013). Nigeria Economic Outlook. Retrieved from http://www.afdb.org/en/countries/west-africa/nigeria/

Agunga, R. (1992). Development by Rules: An ethical reflection on the high failure rate of development projects and implications for communication. Africa Media Review, 6(10), 1-13.

Akinyokun, O. C., Angaye C. O., \& Ubaru, M. O. (2009). Factor analysis of the performance indices of ICT projects in the public sector of Nigerian economy. Journal of Technology Research, 1, 1-15.

Ameh J. O., \& Odusami, K. T. (2010). Professionals' ambivalence toward ethics in the Nigerian construction industry. Journal of Professional Issues in Engineering Education and Practice, 136(1), 9-16. http://dx.doi.org/10.1061/(ASCE)1052-3928(2010)136:1(9)

Atkinson, R. (1999). Project management: Cost, time and quality, two best guesses and a phenomenon, it's time to accept other criteria. International Journal of Project Management, 17(6), 337-342. http://dx.doi.org/10.1016/S0263-7863(98)00069-6

Babalola, D. (2014). The underdevelopment of Nigeria's Niger Delta Region: Who is to blame? Journal of Sustainable Development, 7(3), 118-128. http://dx.doi.org/ 10.5539/jsd.v7n3p118

Baccarini, D. (1999). The logical framework method for defining project success. Project Management Journal, $30(4), 25-32$.

Belassi,W., \& Tukel, O. I. (1996). A new framework for determining critical success/failure factors in projects. International Journal of Project Management, $14(3), \quad 141-151$. http://dx.doi.org/10.1016/0263-7863(95)00064-X

Bryman, A., \& Bell, E. (2011). Business research methods (3rd ed.). Oxford: Oxford University Press.

Cleland, D. I., \& Gareis, R. (2006). Global Project Management Handbook (2nd ed.). New York: McGraw-Hill.

Cooke-Davies, T. (2002). The "real" success factors on projects. International Journal of Project Management, 20(3), 185-190. http://dx.doi.org/ 10.1016/S0263-7863(01)00067-9

Creswell, J. W. (2009). Research design: Qualitative, quantitative, and mixed methods approaches (3rd ed.). California: Sage.

Daily Times. (2013). Presidential committee on NDDC submits report. Retrieved from http://www.dailytimes.com.ng/article/presidential-committee-nddc-submits-report

Dvir, D. (2005). Transferring projects to their final users: the effect of planning and preparations for commissioning on project success. International Journal of Project Management, 23(4), 257-265. http://dx.doi.org/ 10.1016/j.ijproman.2004.12.003

Enagi, M. A., \& Ochoche, A. (2013). The role of enterprise architecture in aligning business and information technology in organisations: Nigerian Government Investment on Information Technology. International Journal of Engineering and Technology, 3(1), 59-65.

Ewa, U. E. (2013). Root Causes of project abandonment in tertiary institutions in Nigeria. International Business Research, 6(11), 149-159. http://dx.doi.org/10.5539/ibr.v6n11p149

Felix, J. M., \& Wilson, G. (2011). The Underdevelopment of Nigeria: Who is to Blame-Failure of Leadership or Her Political Economic System? Lwati: A journal of Contemporary Research, 8(3), 267-279.

Foster, V., \& Pushak, N. (2011). Nigeria's Infrastructure: A continental perspective. New York: The World Bank.

Ghauri, P. N., \& Gronhaug, K. (2010). Research methods in business studies (4th ed.). London: FT Pearson.

Heeks, R. (2002). E-Government in Africa: Promise and practice. Retrieved at http://www.sed.manchester.ac.uk/idpm/research/publications/wp/igovernment/documents/igov_wp13.pdf

Igbokwe-Ibeto, C. J. (2012). Issues and challenges in local government project monitoring and evaluation in Nigeria: The way forward. European Scientific Journal, 8(18), 180-195.

Ika, L. A. (2012). Project management for development in Africa: Why projects are failing and what can be done about it. Project Management Journal, 43(4), 27-41. http://dx.doi.org/ 10.1002/pmj.21281

Ika, L. A. (2009). Project success as a topic in project management journals. Project Management Journal, 40(4), 6-19. http://dx.doi.org/ 10.1002/pmj.20137 
International Fund for Agricultural Development (2009). Country programme evaluation federal republic of Nigeria. Italy.

Jugdev, K., \& Muller, R. (2005). A retrospective look at our evolving understanding of project success. Project Management Journal, 36(4), 19-31. http://dx.doi.org/ 10.1109/EMR.2006.261387

Kakonge, J. O. (1995). Dilemmas in the design and implementation of agricultural projects in various African countries: The role of environmental impact assessment. Environmental Impact Assessment Review, 15(3), 275-285. http://dx.doi.org/ 10.1016/0195-9255(95)00007-2

Koi-Akrofi, G. Y., Quarshie, H. O., \& Koi-Akrofi, J. (2013). IT Project Failures in Organizations in Ghana. Journal of Emerging Trends in Computing and Information Science, 4(1), 100-107.

Lim, C. S., \& Mohamed, M. Z. (1999). Criteria of project success: An explanatoryre-examination. International Journal of Project Management, 17(4), 243-248. http://dx.doi.org/ 10.1016/S0263-7863(98)00040-4

Mobereola, D. (2009). Lagos Bus Rapid Transit Africa's first BRT scheme SSATP Discussion Paper No. 9. Retrieved

from http://siteresources.worldbank.org/EXTAFRSUBSAHTRA/Resources/1513929-1267048793041/DP09-Lag os-BRT.pdf

Muller, R. (2009). Project governance. Farnham, UK: Surrey Gower Publishing Ltd.

Nelson, R. R. (2005). Project retrospectives: Evaluating project success, failure, and everything in between. MIS Quarterly Executive, 4(3), 361-372.

Nwachukwu, C. C. (2009). Client's constraining factors to construction project management success in Nigeria: a systems analytical approach. International Journal of Development and Management Review, 4(1).

Obayelu, A. E. (2007). Effects of corruption and economic reforms on economic growth and development: Lessons from Nigeria. Being a paper prepared and submitted For the African Economic Conference. Addis Ababa, Ethiopia.

Odedairo, B. O., Oke, M. O., \& Oyalowo, B. A. (2011). Achieving sustainable infrastructural development in developing nations: Project Management Education to the Rescue.Management science and engineering, 5(4), 7-15. http://dx.doi.org/10.3968\%2Fj.mse.1913035X20110504.160

Offshore Technology. (n.d.). Bonga Deepwater Project, Niger Delta, Nigeria. Retrieved from http://www.offshore-technology.com/projects/bonga/

Okereke, O. C. (2012). A long-term project management analysis of the recent $\$ 1.1$ billion Chinese loan to Nigeria. PM World Journal, 1(4), 1-7.

Okonjo-Iweala, N., \& Osafo-Kwaako, P. (2007). Nigeria's economic reforms: Progress and challenges. Retrieved from http://www.brookings.edu/ /media/Files/rc/papers/2007/0323globaleconomics_okonjo\%20iweala/2007032 3okonjo_iweala.pdf

Okorafor, G. F., \& Adu, E. T. (2010). Infrastructural project execution drag and integrated development: selected cases in Nigeria. Interdisciplinary Journal of Contemporary Research in Business, 2(2), 557-569.

Olalusi, O., \& Otunola, A. (2012). Abandonment of building projects in Nigeria -Review of Causes and Solutions, International Conference on Chemical, Civil and Environment Engineering.

Oyewobi, L. O., Ganiyu, B. O., Oke, A. A., Ola-Awo, A. W., \& Shittu, A. A. (2011). Determinants of unethical performance in Nigerian construction industry. Journal of Sustainable Development, 4(4), 175-182. http://dx.doi.org/ 10.5539/jsd.v4n4p175

Pinto, J., \& Slevin, D. (1988). Project success: definitions and measurement techniques. Project Management Journal, 19(1), 67-71.

Pinto, J. K., \& Mantel, S. J. (1990). The causes of project failure. IEEE Transactions on Engineering Management, 37(4), 269-276. http://dx.doi.org/10.1109/17.62322

Project Management Institute. (2008). A Guide to the Project Management Body of Knowledge (4th ed.). Pennsylvania: Project Management Institute Inc.

PWC. (2014). Capital project and infrastructure spending Outlook to 2025. Retrieved from http://www.pwc.com/gx/en/capital-projects-infrastructure/publications/cpi-outlook/assets/cpi-outlook-to-20 25.pdf 
Raz, T., \& Michael, E. (2001). Use and benefits of tools for project risk management. International Journal of Project Management, 19(1), 9-17. http://dx.doi.org/ 10.1016/S0263-7863(99)00036-8

Sahoo, P., \& Dash, R. K. (2009). Infrastructure development and economic growth in India. Journal of the Asia Pacific economy, 14(4), 351-365.

Srinivasu, B., \& Rao, P. S. (2013). Infrastructure Development and Economic growth: Prospects and Perspective. Journal of Business Management \& Social Sciences Research, 2(1), 81-91.

Subsea7. (2011). Addax Okwori and Antan. Retrieved from http://www.subsea7.com/content/dam/subsea7/documents/whatwedo/projects/africaandgulfofmexico/Adda xOkworiAntan.pdf

Thomas, G., \& Fernandez, W. (2008). Success in IT projects: A matter of definition? International Journal of Project Management, 26(7), 733-742. http://dx.doi.org/10.1016/j.ijproman.2008.06.003

Ubani, E. C., Nwachukwu, C. C., \& Nwokonkwo, O. C. (2010). Variation factors of project plans and their contributions to project failure in Nigeria. American Journal of Social and Management Sciences, 1(2), 141-149. http://dx.doi.org/ 10.5251/ajsms.2010.1.2.141.149

Uma, K. E., Eboh, F. E., Obidike, P. C., \& Ogwuru, H. O. R. (2013). Poverty, Underdevelopment and Emerging Economies: Nigeria in Focus. Global Journal of Management and Business Research Finance, 13(6).

Vision 2020 National Technical Working Group Report. (2009). Retrieved from http://www.npc.gov.ng/vault/files/human\%20development\%20ntwg\%20report.pdf

Wateridge, J. (1998). How can IS/IT projects be measured for success? International Journal of Project Management, 16(1), 59-63. http://dx.doi.org/ 10.1016/S0263-7863(97)00022-7

Westerveld, E. (2003). The project excellence model: linking success criteria and critical success factors. International Journal of Project Management, 21(6), 411-418. http://dx.doi.org/10.1016/S0263-7863(02)00112-6

White, D., \& Fortune, J. (2002). Current practices in project management an empirical study. International Journal of Project Management, 20(1), 1-11. http://dx.doi.org/ 10.1016/S0263-7863(00)00029-6

World Bank. (2013). Nigeria Country Information. Retrieved from http://web.worldbank.org/WBSITE/EXTERNAL/COUNTRIES/AFRICAEXT/NIGERIAEXTN/0,,menuPK :368902 pagePK:141159 piPK:141110 theSitePK:368896,00.html

Zwikael, O., \& Globerson, S. (2004). Evaluating the quality of project planning: a model and field results. International Journal of Production Research, 42(8), 1545-1556. http://dx.doi.org/10.1080/00207540310001639955

Zuofa, T., \& Ochieng, E. G. (2012). Towards The Advancement of Project Management Practice in Developing Countries: The Case of Nigeria. PMI Research and Education Conference Limerick Ireland, 15-18 July 2012, Limerick, Ireland.

\section{Appendix A - Focus Group discussion Questions}

All information provided will be treated as confidential.

\section{Engagement/general Questions}

1. Describe your role and responsibility in your organisation?

2. What category of projects have you been involved in and for how long?

\section{Exploration/probing Questions}

1. Have you always been satisfied with the outcome of your projects?

2. How best can successful projects be described?

3. In your own words, define project failure?

4. What are the indicators of project failure?

5. Relieve your experience on project failure from past experiences, what went wrong/ right in those projects?

6. What were the most common factors that the led to failures in projects you have been involved with? 


\section{Exiting questions}

1. What are your thoughts on curbing project failure in Nigeria in the future?

\section{Copyrights}

Copyright for this article is retained by the author(s), with first publication rights granted to the journal.

This is an open-access article distributed under the terms and conditions of the Creative Commons Attribution license (http://creativecommons.org/licenses/by/3.0/). 